\section{Discovery of waisted axes in New Guinea}

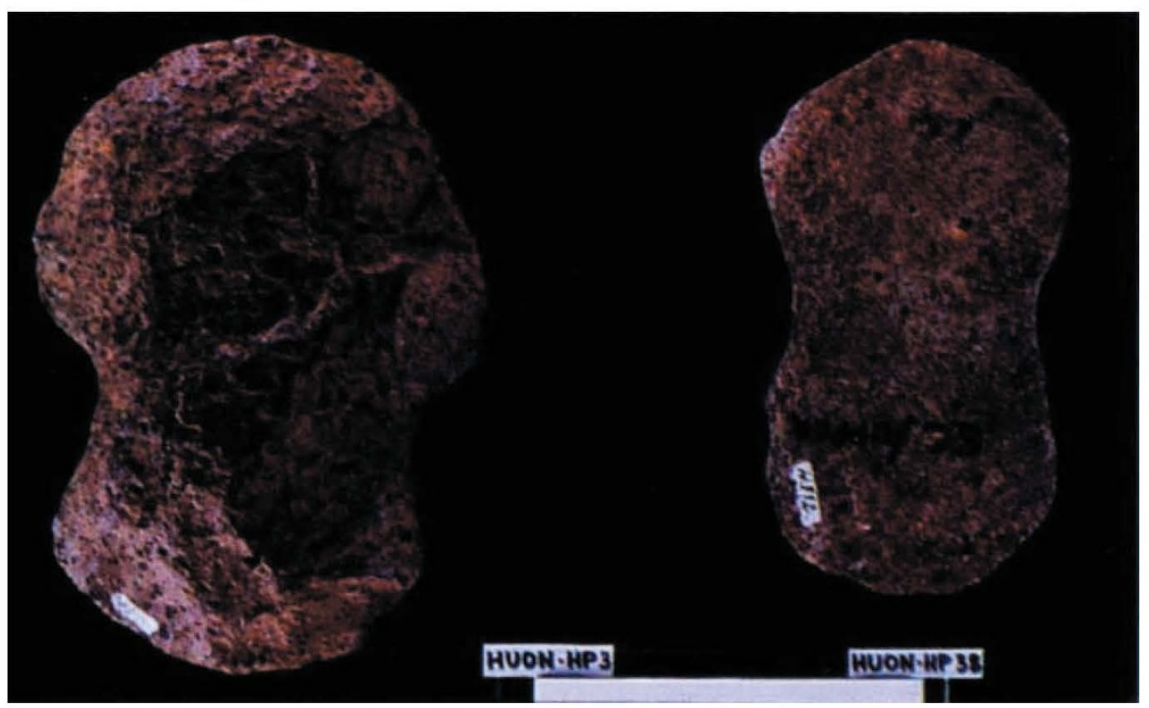

THE recent discovery of waisted axes such as those pictured above indicates that human inhabitants were present in Papua New Guinea more than $\mathbf{4 0 , 0 0 0}$ years ago. On page 453 of this issue, Les Groube and his co-workers describe the excavation undertaken (at the south-east end of the Huon Peninsula in New Guinea) and the artefacts discovered there. The archaeological site consists of a series of coral terraces of varying ages, the waisted axes being localized to regions believed to be more than $\mathbf{1 0 , 0 0 0}$ years old. This dating was confirmed by thermoluminescence analysis of resident quartz particles. These new data suggest that New Guinea was inhabited at a relatively early stage in the Pleistocene settlement of Australia from the IndonesianIndochina region, when it and Australia were connected by a land bridge.

\section{Albert Szent-Györgi (1893 - 1986)}

AlBert Szent-Györgyi, one of the most remarkable biochemists of our century, died in Woods Hole, Massachusetts, on 22 October. The son of a Hungarian well-todo farmer, he grew up in a comfortable and cultivated household. He had started to study physiology when he was called up for military service in World War I. In the post-war upheavals he wandered from one laboratory to another, learning new techniques from Michaelis and others, until he settled in Holland, first in Leiden and then with H.J. Hamburger in Groningen. He became deeply interested in biological oxidations, especially the catalytic systems involving succinate, fumarate, malate and oxaloacetate. He recognized their wide general significance in metabolism, and his work represented an important preliminary step that helped toward the later demonstration of the total tricarboxylic acid cycle by Hans Krebs.

Szent-Györgyi also became intereșted in vegetable respiration, and detected a reducing agent, present in many plant juices, which he noted because it caused a slight delay in the progress of oxidations catalysed by peroxidases. That he took notice of this slight delay, which many investigators might have ignored, was characteristic. When Hamburger died, SzentGyörgyi had to find a job elsewhere; by great good fortune Sir Frederick Hopkins, who had followed his work with interest, invited him to Cambridge and obtained a fellowship for him. Here he succeeded in crystallizing the reducing agent from the juice of oranges, lemons and cabbages, and from adrenal glands.

About this time (1932) an enlightened Hungarian minister of education recognized Szent-Gyögyi's ability and invited try at the University of Szeged. A young Hungarian, J. Swisbely, who was familiar with the assay for vitamin $C$, came to work with him. It was soon apparent that the crystalline reducing agent was indeed vitamin C (ascorbic acid). Szent-Györgyi found that Hungarian paprika was extraordinarily rich in this substance, and was able to prepare crystals in kilogram quantities, which he distributed to other researchers throughout the world. It was for his work on ascorbic acid that he received the Nobel Prize in 1937; the citation also noted the importance of his work on the role of dicarboxylic acid anions in biological oxidation systems.

Next he became involved in the study of muscle contraction and the proteins of muscle. On extracting myosin with salt solutions by the standard procedures, he noted that, if the extraction was prolonged, the extract became considerably more viscous, although the total amount of protein extracted was not much greater. This led to the recognition that another him back as professor of medical chemis- protein, later called actin, was associated with myosin. Szent-Györgyi's young coworker, F.B. Straub, purified actin, while he himself investigated the ATP-induced contractility of actomyosin threads.

Szent-Györgyi carried out this work. which opened great new vistas in muscle biochemistry, during World War II under constant danger from the Nazis, who had become aware of his contacts with the British Secret Service. He was placed under house arrest, and escaped seizure by the Gestapo only by taking refuge in the Swedish Legation in Budapest. When the Nazis broke into the Legation, he fled just in time, and he and his wife went into hiding until the war ended.

When the Soviet armies arrived. SzentGyörgyi and his family were protected and well cared-for on personal orders from Molotov, and later he was brought to Moscow for two months. But he became disillusioned and outraged by the character of the Soviet regime and the atrocities committed by the Soviet armies in Hungary. Although personally well treated by the authorities, he found it impossible to continue the work of his laboratory and so departed for the United States, where he settled at the Marine Biological Laboratory in Woods Hole.

Always ready to strike out into new fields, he became fired with interest in the concepts of quantum mechanics, although he never claimed to have mastered (or even to have actually grasped) the mathematical complexities of the subject. Along these lines, he wrote a small monograph on what he termed 'submolecular biology'.

His major preoccupation during the last decades of his life, however, was with cancer. His views on the origins of cancer differed widely from those of almost all other workers in the field, and government grants for his support, although available in limited amounts, were quite inadequate to support research on the scale that he considered necessary. He continued research with a small group, but his last years must have been embittered with a sense of frustration.

He was always, especially in his earlier years, a man of infinite jest; he loved to announce his ideas and discoveries in a manner that could lead the unwary to believe that he was talking nonsense: but they soon discovered that there was a very solid basis for it all. Like many jesters, he had a deeply tragic vision of the world; he was appalled by the follies of its rulers. teetering constantly on the brink of destruction. Somehow he still managed to cherish hope. Scientist and humanist, he was a unique and unforgettable man.

John T. Edsall

John T. Edsall is in the Department of Biochemistry and Molecular Biology. Harvard University, Cambridge, Massachusetts 02138, USA 